\title{
Problems of Women Education in India (A Case Study of Mangalagiri Mandal in Guntur District of A.P)
}

\author{
Sudhir Maddela1, Pradeep M. ${ }^{2}$ \\ ${ }^{1}$ Associate Professor, ${ }^{2}$ Research Scholar, \\ ${ }^{1}$ Nirmala College of Pharmacy, Atmakur, Mangalagiri Mandal, Guntur, Andhra Pradesh, India \\ ${ }^{2}$ VTJM \& IVTR Degree College, Mangalagiri Mandal, Guntur, Andhra Pradesh, India
}

\begin{abstract}
How to cite this paper: Sudhir Maddela | Pradeep M. "Problems of Women Education in India (A Case Study of Mangalagiri Mandal in Guntur District of A.P)" Published in International Journal of Trend in Scientific Research and Development (ijtsrd), ISSN: 24566470, Volume-3 | Issue-3 , April 2019, pp.1069-1073, URL: https://www.ijtsrd.c om/papers/ijtsrd23 148.pdf

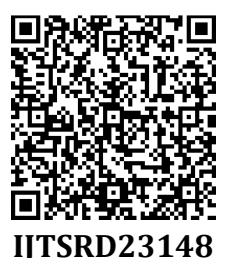

Copyright (C) 2019 by author(s) and International Journal of Trend in Scientific Research and Development Journal. This is an Open Access article distributed under the terms of the Creative Commons

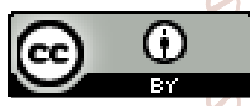
Attribution License (CC BY 4.0) (http://creativecommons.org/licenses/ by $/ 4.0$ )

\section{Introduction}

Education is the process that liberates the mind. It is liberation from all forms of darkness and ignorance. Women's literacy is essential for economic viability and independence. Acquisition of knowledge is one of the prerequisites of human development. Today all development agencies agree on the importance of educating women in order to promote and maintain family education, health, nutrition and general well-being. The aim of education should be to train women in such a way that they apply their acquired knowledge to the pursuits of daily life and fit them for the position they have to fill. Education for women should always be directed towards their holistic development. Education enhances a woman's sense of her own health needs and perspectives and her power to make any health and family planning decisions. This in turn, helps to reduce child and maternal mortality and morbidity rates. The increase in the education of women and girls contributes to greater empowerment of women, to a postponement of the age of marriage and to a reduction in the size of the families.

\section{ABSTRACT} improve become essential for sustainable development roved livelihoods and the competitiveness of the economy. Education and Exth and to build human capacity for rural development. development. Today all development agencies agree on the importance of daily life and fit them for the position they have to fill.

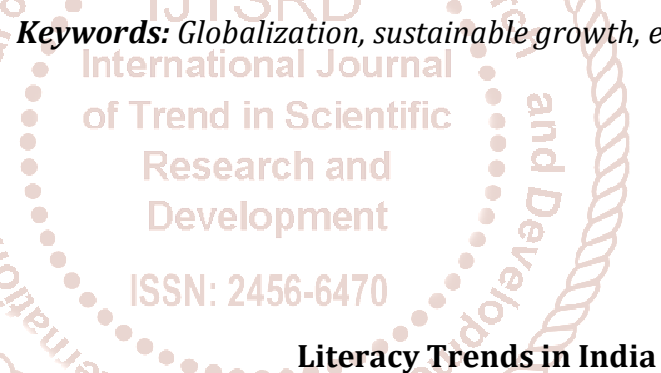

At the time of Independence, India inherited an educational system which was not only qualitatively small but also characterised by striking regional and structural imbalances. Only 14 per cent of the population were literates and one child out of three had been enrolled in primary school. Inspite of the expansion in the formal education system, most of the Indian women have reminded outside the reach of education.

Social and economic development of a country depends on its best literacy rates and better educational facilities. In our country, though the literacy rate has been increasing female literacy is lower than male literacy. According to 2011 census, the literacy percentage of India was 74.04 per cent, whereas, in the case of women it was 65.46 per cent. The main aim of presenting the literacy levels of women in our country is to highlight the prevailing disparities in the literacy rate between males and females and it also indicates regional variations and points out the areas that need special attention. The percentage of literates indicated in Table l. 
International Journal of Trend in Scientific Research and Development (IJTSRD) @ www.ijtsrd.com eISSN: 2456-6470

Table 1 Percentage of literates in India and Andhra Pradesh

\begin{tabular}{|c|c|c|c|c|c|c|}
\hline \multirow{2}{*}{ Year } & \multicolumn{3}{|c|}{ India } & \multicolumn{3}{c|}{ Andhra Pradesh } \\
\cline { 2 - 7 } & Male (\%) & Female (\%) & Persons (\%) & Male (\%) & Female (\%) & Persons (\%) \\
\hline 1901 & 9.8 & 0.7 & 5.5 & 8.5 & 0.6 & 4.6 \\
\hline 1911 & 10.6 & 1.1 & 6.0 & 9.2 & 0.9 & 5.1 \\
\hline 1921 & 12.2 & 1.8 & 7.2 & 10.9 & 1.6 & 6.3 \\
\hline 1931 & 15.6 & 2.9 & 9.5 & 11.7 & 1.8 & 6.8 \\
\hline 1941 & 24.9 & 7.3 & 16.1 & 16.8 & 5.0 & 11.0 \\
\hline 1951 & 24.9 & 7.9 & 16.7 & 22.7 & 7.6 & 15.2 \\
\hline 1961 & 34.4 & 13.0 & 24.0 & 30.2 & 12.0 & 21.2 \\
\hline 1971 & 39.5 & 18.7 & 29.5 & 33.2 & 15.7 & 24.6 \\
\hline 1981 & 41.0 & 20.0 & 35.8 & 39.2 & 20.4 & 29.9 \\
\hline 1991 & 64.1 & 39.3 & 52.3 & 35.1 & 32.7 & 44.1 \\
\hline 2001 & 75.8 & 52.1 & 65.4 & 70.8 & 51.2 & 61.1 \\
\hline 2011 & 82.14 & 65.46 & 74.04 & 74.8 & 60.0 & 67.4 \\
\hline
\end{tabular}

Source: Computed from census reports.

The literacy levels in India and Andhra Pradesh during 1901 to 2011 are presented in Table 1. The data shows that literacy rates had increased from 5.5 per cent in 1901 to 74.4 in.2011 for India while for the state of Andhra Pradesh it rose from 4.6 per cent to 67.4 per cent during this period. With regard to the literacy rates by sex, it is evident that for males it is recorded as above 80 per cent and 65 per cent in case of females for the country as a whole and almost the similar figures can be noticed for the State of Andhra Pradesh in 2011.

Table 2 Gender-wise, Area-wise literacy rates in Andhra Pradesh during 1961 to 2001

\begin{tabular}{|c|c|c|c|c|}
\hline \multirow{2}{*}{ Year } & Rural Area & & Urban Area & \\
\cline { 2 - 5 } & Male & Female & Male & Female \\
\hline 1961 & 25.14 & 8.45 & 53.62 & 29.33 \\
\hline 1972 & 27.31 & 10.92 & 57.30 & 36.31 \\
\hline 1981 & 32.25 & 14.08 & 61.89 & 41.55 \\
\hline 1991 & 47.28 & 23.92 & 75.81 & 56.41 \\
\hline 2001 & 57.31 & 38.55 & 6477.54 & 61.33 \\
\hline 2011 & 69.38 & 51.29 & 85.79 & 73.31 \\
\hline
\end{tabular}

Source: Andhra Pradesh Director, 1991 and Census of India 2011.

The Table 2 reveals that the literacy rate in rural areas is lower than urban areas and it also shows that female literacy is lower than male literacy in both rural and urban areas of Andhra Pradesh from 1961 to 2011. In 1961, female literacy rate in rural areas was 8.45 per cent whereas in urban areas, it was 29.33 per cent. In 2011, these rates increased to 51.29 per cent and 73.31 per cent respectively.

Table 3 Literacy rates in post-Independent India

\begin{tabular}{|c|c|c|c|c|c|c|c|c|c|}
\hline \multirow{2}{*}{ Year } & \multicolumn{3}{|c|}{ Rural } & \multicolumn{3}{c|}{ Urban } & \multicolumn{3}{c|}{ Combined cent) } \\
\cline { 2 - 11 } & Female & Male & Total & Female & Male & Total & Female & Male & Total \\
\hline 1951 & 4.87 & 19.02 & 12.01 & 22.3 & 45.6 & 34.5 & 8.8 & 27.1 & 18.3 \\
\hline 1961 & 10.1 & 34.3 & 22.5 & 40.5 & 66 & 54.4 & 15.3 & 40.4 & 28.3 \\
\hline 1971 & 15.5 & 48.6 & 27.9 & 48.8 & 69.8 & 60.2 & 21.9 & 45.9 & 34.4 \\
\hline 1981 & 21.7 & 49.6 & 36 & 56.3 & 76.7 & 67.2 & 29.7 & 56.3 & 43.5 \\
\hline 1991 & 30.17 & 56.9 & 36 & 64.0 & 81.0 & 67.2 & 39.2 & 64.1 & 52.2 \\
\hline 2001 & 46.7 & 71.4 & 59.4 & 73.2 & 86.7 & 80.3 & 53.6 & 75.2 & 64.8 \\
\hline 2011 & 58.75 & 78.5 & 67.8 & 79.9 & 89.6 & 84.1 & 65.4 & 82.1 & 74.0 \\
\hline $\begin{array}{c}\text { \% increase in } \\
\mathbf{2 0 1 1} \text { over 2001 }\end{array}$ & $\mathbf{2 6 \%}$ & $\mathbf{1 0 \%}$ & $\mathbf{1 4 \%}$ & $\mathbf{9 \%}$ & $\mathbf{3 \%}$ & $\mathbf{5 \%}$ & $\mathbf{2 2 \%}$ & $\mathbf{9 \%}$ & $\mathbf{1 4 \%}$ \\
\hline
\end{tabular}

Source: Census of India, Office of the Registrar General, Delhi, India.

Table 3 explains the literacy rates in post-independent India. The total literacy rate is 18.3 per cent in 1951 and increased to 74 per cent in 2011. The female literacy is 8.8 per cent in 1951 and increased to 65.4 per cent in 2011. The female literacy increases to 22 per cent in 2011 over 2001. 


\section{Objectives}

The objectives of this paper is:

1. To study the problems of women education.

2. To analyse the reasons for school dropouts.

3. To study the programmes for women literacy.

\section{Data}

Both primary and secondary data is used. Primary data is directly collected from the respondents of the Mangalagiri mandal of Guntur district. Secondary data is collected from the various census reports

\section{Methodology}

Mangalagiri mandal of Guntur district is purposely chosen for the study. 150 samples were selected to explain the reasons for dropouts.

\section{Literacy in Guntur District}

Guntur district occupies $7^{\text {th }}$ place in terms of literacy in the state of Andhra Pradesh. According to 2001 census, literacy rate of Guntur district is 55.54 per cent, it is 62.96 per cent for males and 48.00 per cent for females. As per 2011 census, the male literacy is 83.97 per cent and for females is 72.25 per cent. The female literacy in the district has been increasing but it is low when compared to male literacy.

\section{Review of Literature}

Karuna Chanana (1990) ${ }^{1}$ discusses briefly the developments in the education of girls and women since independence. It begins with literacy rate, enrolment in school education and higher education and highlights the regional variations. Further, more the difference in the rural-urban areas and also among the disadvantaged groups such as the scheduled castes and the scheduled tribes are also discussed. Thus, while discussing the developments, the aim is to pinpoint the positive as well as the negative trends and the imbalances in the growth and expansion of girl s education. Lastly, we shall try to discuss the factors and processes that hinder girls education and suggest ways and means of ameliorating the same.

Uniyal (1996) ${ }^{2}$ observed that by educating a man, we educate only one person but while educating a woman we educate an entire family. This observation bears testimony to the testimony to the importance of female education. The education of the rural women cannot be overemphasized. Pandit Nehru, the architect of modern India, some people see and think that education is not so important as putting up a factory. He sacrifice any number of factories. But he will not sacrifice human beings who set up factories and produce the things we want.

According to Uma Devi, K. (2000) ${ }^{3}$ education brings perfection to life which means the growth and development of personality. It qualifies a person to fulfil certain economic, political and-cultural functions and thereby improves the socio-economic states of the people. It also helps to equalize

\footnotetext{
${ }^{1}$ Karuna Chanana. "Education of Girls, a Sociological Perspective", Kurukshetra, September, 1990, Vol. XXXVIII, No.12.

2 Uniyal, B.L. "Women Education Haringer of Rural Prosperity”, Kurukshetra, Vol. XLIV, No.11, Aug. 1996.

${ }^{3}$ Uma Devi K., "Women's Education what direction”, Social Welfare, Sept. 2000, Vo1.47, No.6.
}

the status of individuals who belong to different social strata. The constitution of India contemplates a social change to be brought in though the use of low as an instrument. The attainment of equality of states for women is one of the objectives which is implicit in the preamble, the fundamental rights and the directive principles of state policy. But social change is a compute process and that change is not always true to the constitutional directives.

According to Neelima arid Shyam Swaroop (2000) ${ }^{4}$ education improves the quality of life. It promotes a better health, expands access to employment, increases market productivity and facilities social and economic participation. It is an important form of human capital that improves productivity, health and nutrition of the people of a country and slows down population growth. Education is an important too of 'social mobility' and 'social empowerment'. Education enables a person to develop a sense of identity, recognition and self-worth. Right from booking tickets at counters to applying loans establishing one's legal rights, education helps a person in all facts of life irregularly. Also a large percentage of those enrolled drop-out after Class-V. This means that not all children are benefited from formal school system. Moreover, the first generation students lack encouragement and a congenial atmosphere at home. As the parents themselves are illiterate and ignorant, they have little value for education. Children are viewed as potential wage earners who could supplement low family incomes.

Mandakini Pant (2004) ${ }^{5}$, remarks that out of an estimated 1.2 billion poor people in the worlds, over two-thirds are women. They face object poverty in want of adequate food, clean water, sanitation and health care. They often lack access to the critical resources of credit, land and inheritance. They are denied opportunities, choices, access to information, education and skills without any sense of power whatsoever, their participation in division making is minimal, both at home and in the community.

Kukreti B.R. (2004) 6 argues that the enrolment ratio of children in schools is very low in tribal areas while on the other hand the dropout rate continuous to be very high at all levels of education. In the present study an effort has been made to find out the causes of dropout among tribal students and to give some suggestions which may be helpful in reducing dropout rate among tribal students. The root cause of dropout is the prevailing illiteracy and ignorance of parents. Even after-intensive literacy drive more than 50 per cent of the population is still illiterate. No doubt awareness about education has increased in rural tribal masses but the habitual inhibition and family imperatives still hampers the attempts to send their wards regularly to schools.

\section{Problems of Women Education}

The problems of women illiteracy has also been enhanced due to low enrolment and high dropout rates among girls who enter the formal system of education. While the

\footnotetext{
${ }^{4}$ Neelima, B.N. and Shyam Swaroop, T. "Putting the Girl child in School", Social Welfare, Sept. 2000, Vol.47, No.6.

5 Mandakini Pant. "Adult Education and Livelihood, Women as agents of change", Adult Education, 2004, p.63. ${ }^{6}$ Kulkreti, B.R. "Dropout problem among tribal students at school level”, Kurukshetra, Sept. 2004, Vol. XXXVIII, No.12.
} 
enrolment of girls in the schools has shown a study increase, it is still not commensurate with the enrolment rate of boys. The dropout rate among girls, particularly those who live in rural areas, continuous to be very high. In the light of these facts, major reasons for low literacy rate among women are listed below:

A. Early marriage and dowry.

B. Reluctance to send girls out of the house after puberty.

C. High intensity of poverty and parent's inability, to bear educational expenses.

D. Lack of access of schools.

E. Shortage of women teachers.

F. Lack of infrastructure facilities which lead to low enrolment and large dropouts.

G. Need for girls to help in the farms or family occupation or household chores or responsibility of looking after younger siblings:

Most parents believe that education is good for girls, but many parents, especially among the poor, do not send their daughters to school. Because, their daughters are needed for agricultural and household production tasks as well as for domestic chores such as cooking and looking after younger siblings. In addition to the opportunity cost of daughter's labour, there are the actual costs of clothes, school fees and books. These costs discourage poor parents yet for sons, families are often willing to forgo their labour and even incur with his own family's after marriage and contribute to household earnings. In contrast, education for a girl's only increases the cost to her natal family of getting her married, since a suitable and more educationally qualified groom requires a longer dowry. Any economic benefit from her future earnings would accrue to her-family.

\section{Causes of dropouts}

1. Illiterate and ignorant parents.

2. Poverty/economic problems.

3. Early-marriages:

4. Non-stimulating social environment,

5. Semi-settled tribal life.

6. Migratory nature.

7. Discouraging school environment

8. Need of students at farm and pastureland,

9. Participation of children in household economic activities.

10. Language difficulty.

11. No immediate gain from children.

12. Reluctance of parents and have to work for wage/salary.

13. Have to participate in domestic activities.

14. Teachers' unfair behaviour.

Table 4 Year-wise Dropout Rates from 2004-05 to 2012-13 (All) in Andhra Pradesh

\begin{tabular}{|c|c|c|c|c|}
\hline S. No. & Years & Classes I-V & Classes I-VII & Classes I-X \\
\hline 1 & $2004-05$ & 22.31 & 48.12 & 64.55 \\
\hline 2 & $2005-06$ & 17.36 & 44.31 & 63.45 \\
\hline 3 & $2006-07$ & 19.11 & 38.87 & 62.96 \\
\hline 4 & $2007-08$ & 11.75 & 31.25 & 60.95 \\
\hline 5 & $2008-09$ & 7.69 & 29.83 & 56.35 \\
\hline 6 & $2009-10$ & 8.93 & 21.03 & 50.18 \\
\hline 7 & $2010-11$ & 9.55 & 15.66 & 44.19 \\
\hline 8 & $2011-12$ & 7.45 & 14.95 & 41.98 \\
\hline 9 & $2012-13$ & 6.08 & 20.38 & 33.41 \\
\hline
\end{tabular}

Source: Commissioner, Director of School Education, Government of Andhra Pradesh, Hyderabad.

Table 4 explained about the dropouts from 2004-05 to 2012-13. The percent is gradually decreasing. It is 64.55 in $2004-05$ decreased to 33.41 per cent in 2012-13.

Table 5 Reasons for Dropouts

\begin{tabular}{|c|c|c|c|c|c|c|}
\hline S. No. & Reason & SC & ST & BC & Others & Total \\
\hline 1 & Reluctance of parents & $5(13.89)$ & $3(7.50)$ & $4(10.53)$ & $6(16.67)$ & $18(12.00)$ \\
\hline 2 & Poverty & $18(50.00)$ & $24(60.00)$ & $15(39.47)$ & $11(30.35)$ & $68(45.33)$ \\
\hline 3 & Death of the parent & $10(27.78)$ & $11(27.50)$ & $12(31.58)$ & $14(38.89)$ & $47(31.33)$ \\
\hline 4 & Need of the girl for work & $3(8.33)$ & $2(5.00)$ & $7(18.42)$ & $5(13.89)$ & $17(11.34)$ \\
\hline & Total & $36(100.00)$ & $40(100.00)$ & $38(100.00)$ & $36(100.00)$ & $150(100.00)$ \\
\hline
\end{tabular}

Source: Primary data

When parents are asked to give details about the dropouts they have expressed the reasons. They are explained in Table 5. It is evident from the table 5 majority dropouts are due to the poverty of the family. 68 members i.e. 45.33 per cent have expressed that their children are discontinued school because of poverty followed by death of parents. 31 per cent of children dropped because their parents are dead.

\section{Government programmes for women literacy}

The Government of India had taken various steps to improve literacy in India and introduced various programmes in this regard. They are:

Mahila Samakhya: Mahila Samakhya started in 1989, the Mahila Samakhya scheme recognises the centrality of education in empowering women to achieve equality. Presently the scheme is being operated in more than 8,000 villages in 53 districts spread in the states of Andhra Pradesh, Assam, Bihar; Gujarat, Karnataka, Kerala, Madhya Pradesh and Uttar Pradesh.

Sarva Shiksha Abhiyan: Sarva Shiksha Abhiyan aims at mobilising resources - human, financial and institutional necessary for achieving the goal of Universalisation of elementary education. A national committee of state education Ministers has been constituted under the Chairmanship of the Minister of Human Resource Development. 
Non-formal Education: At present there are 2.92 lakh nonformal education centres covering about 73 lakh children in 25 States/UTs. 1.15 lakh centres exclusively meant for girls receive central assistance upto 90 per cent.

National Literacy Mission: The programme of National Literacy Mission aim at imparting functional literacy to threshold, sustainable level of 75 per cent by the year 2005 . This campaign model is accepted as a dominant strategy for reduction of illiteracy in India.

Navodaya Vidyalaya: The Navodaya Vidyalaya (NV) scheme has a three-fold objective 'of providing good quality modern education to children in rural areas, ensuing attainment of 3 language formula by all students and to serve in each district as focal points for improvement in the quality of school education. These Vidyalayas are fully residential, coeducational institutions, providing education upto the senior secondary stage. Education in NVs include free boarding and lodging, text books, uniforms etc., for all students.

The Kothari Commission, in its report in 1980 said that literacy campaigns must be conducted intensively, specially in the age-group of 15-35 years. A literate women ensures a literate family. Adult .literacy is bound up with universalization of elementary education and retention of girls in secondary schools. A girl who stays in school upto the age of 17 cannot relapse into illiteracy. The two campaigns must be simultaneously conducted.

\section{Conclusion}

Promoting girl's education, therefore, involves changing attitudes across society as well as spending money on increasing the number of school places available to girls. Donors providing funding for education can help by insisting that their funds are used to educate girls as well as boys. New means of engaging policy makers-perhaps through a bottom-up approach, where pressure is applied by civil society, or through better use of evidence to show the benefits of girls' schooling - may also reap rewards. Religious leaders also need convincing, as do men in general, who are usually the main decision-makers within households. Changing cultural attitudes toward women is a slow and difficult process. In nations that have succeeded, such changes have typically required strong political will as well as leadership.

\section{Suggestions}

1. It may be suggested to establish pre-primary schools, primary schools, high schools within rural areas. It may also be suggested to organise orientation programme to the teachers working in rural areas to enable them to discharge the responsibilities in an effective manner.

2. To impart better education and better functioning of the special schools started in rural areas, it may be suggested to appoint committed persons from retired teachers, retired armed personnel etc., so as to reap the fruits of these centres within the time frame work. It is also suggested to provide learning material at free of cost.

3. To eradicate illiteracy in slum areas, it may be suggested to conduct awareness campaigns by the officials, teachers, elected representatives about literacy, uses and need for education etc., for their family and the society as a whole which will in-turn boost up the women literacy.

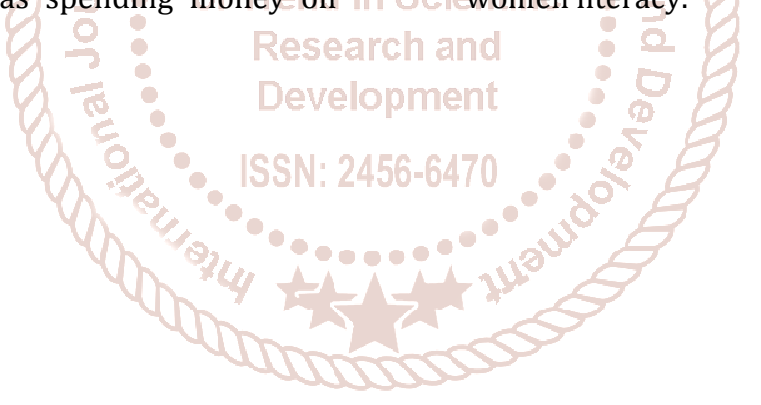

